\title{
KEPASTIAN HUKUM KREDIT ONLINE
}

ONLINE CREDIT LEGAL CERTAINTY

\section{Devy Iziana Pradini, Izzi Zya Hariyadi, Shohibul Khoir*}

Program Studi Magister Kenotariatan Universitas Airlangga

Jalan Dharmawangsa Dalam Selatan 4-6, Surabaya 60286 Indonesia

\section{INFO ARTIKEL}

\section{Riwayat Artikel:}

Diterima : 31 Januari 2020

Disetujui : 04 April 2020

\section{Keywords:}

creditors, online credit, banking

Kata Kunci:

kreditur, kredit online, perbankan

\section{*) Korespondensi:}

E-mail: alapolakhoir@gmail.com

\begin{abstract}
: this paper aims to discuss the validity of a contract in online credit and the provision of collateral for online credit as an embodiment of the $5 \mathrm{C}$ principle in banking. The method of study uses a normative juridical approach to the legislation and conceptual approach. Online credit contracts are legally valid because they meet the legal requirements of a contract, only the legal certainty is low because the parties do not know firsthand the good intentions of the parties. The provision of collateral in online credit is not against the law, it's just that the precautionary principle that the bank should apply in providing credit is not fulfilled. The creditor does not have a guarantee for the debtor's debt repayment if at any time the debtor is unable to repay the loan or break the promise.
\end{abstract}

\begin{abstract}
Abstrak: tulisan ini bertujuan untuk membahas keabsahan suatu perjanjian dalam kredit secara online dan pemberian jaminan pada kredit online sebagai perwujudan prinsip 5C dalam perbankan. Metode kajian menggunakan yuridis normatif dengan pendekatan perundang-undangan dan pendekatan konseptual. Perjanjian kredit online secara hukum sah karena telah memenuhi syarat sahnya suatu perjanjian, tetapi kepastian hukumnya yang rendah karena para pihak tidak mengetahui secara langsung itikad para pihak. Pemberian jaminan dalam kredit online tidak bertentangan dengan hukum, tetapi prinsip kehati-hatian yang seharusnya diterapkan bank dalam memberikan kedit tidak terpenuhi. Kreditur tidak memiliki jaminan atas pelunasan hutang debitur apabila sewaktu-waktu debitur tidak dapat melunasi pinjamannya atau ingkar janji.
\end{abstract}

\section{PENDAHULUAN}

Perkembangan teknologi yang pesat berpengaruh terhadap berbagai aspek kehidupan dalam masyarakat, salah satunya adalah aspek ekonomi. Pertumbuhan ekonomi semakin meningkat, produktivitas semakin meningkat, persaingan usaha di dalam maupun di luar negeri, investasi dan reinvestasi berlangsung secara besar-besaran, dan persaingan dunia kerja yang menuntut pekerja untuk selalu menambah skill dan pengetahuan yang dimilikinya (Hartanto, 2015). Kondisi tersebut menyebabkan perubahan perilaku manusia, tingkat kebutuhan, dan gaya hidup. Gaya hidup masyarakat saat ini serba semerta yang dipengaruhi adanya kemudahan dalam pemenuhan kebutuhan hidup dari internet. Perdagangan pada awalnya menggunakan barter atau pertukaran barang dengan barang, berubah menjadi uang dengan barang. Uang sebagai alat pembayaran pada mulanya hanya berbentuk logam, selanjutnya ada uang kertas. Pada saat ini uang kertas berganti menjadi uang dalam bentuk kartu yang dapat digunakan untuk transaksi jual beli, ada yang berbentuk debit ada pula kartu dalam bentuk kredit (Panginan \& Irwansyah, 2020).

Kegiatan bisnis yang semakin pesat dalam bidang ekonomi menjadikan hutang/kredit sebagai sarana untuk mendukungnya. Seseorang ataupun badan hukum dalam menunjang aktivitas bisnisnya dilindungi oleh hukum yang bertujuan melindungi kepentingan semua pihak. Untuk menjalankan suatu usaha seringkali pelaku usaha membutuhkan lembaga pembiayaan. Permohonan suatu hutang harus disertai dengan jaminan yang dapat memberi kepastian bagi kreditur 
untuk pelunasannya, sehingga pihak yang akan mengajukan pinjaman harus mendatangi bank atau tempat peminjam berada. Kecanggihan teknologi telah mengubah proses pengajuan kredit, pengajuan dan proses peminjaman (hutang) dapat dilakukan secara online. Perkembangan teknologi informasi dan komunikasi, khususnya internet telah berpengaruh terhadap keberadaan pinjaman online secara efektif dan efisien baik pada sisi waktu maupun biaya (Supriyanto \& Ismawati, 2019).Peminjam mengunduh sistem aplikasi dan langsung mengajukan pinjaman melalui aplikasi tersebut. Kesepakatan para pihak dilakukan secara online, tidak dilakukan secara langsung.

Pengertian bank menurut Undang-Undang Nomor 10 Tahun 1998 tentang Perubahan Atas Undang-Undang Nomor 7 Tahun 1992 tentang Perbankan adalah badan usaha yang menghimpun dana dari masyarakat yang berbentuk simpanan dan menyalurkannya kepada masyarakat, berbentuk kredit dan/atau bentuk lainnya yang bertujuan meningkatkan taraf hidup rakyat. Dari pengertian bank tersebut, maka bank memiliki peranan penting untuk menunjang perekonomian nasional, dan juga mengemban tugas amanat pembangunan bangsa demi tercapainya peningkatan taraf hidup rakyat. Untuk melaksanakan visi dan misi tersebut, bank berperan sebagai intermediary institution yang memiliki empat fungsi (Imaniyati, 2010), yaitu sebagai penghimpun dana, pemberi kredit, pemerlancar prosedur pembayaran, dan penyedia informasi (memberikan konsultasi serta bantuan penyelenggaraan administrasi). Bank sebagai intermediary institution berkedudukan sebagai lembaga perantara keuangan masyarakat, menjadi media perantara pihak yang mempunyai kelebihan dana dengan pihak yang kekurangan dana (Imaniyati, 2010).

Pemberian kredit pada nasabah yang dilakukan oleh bank harus memperhatikan prinsip-prinsip dalam penilaian kredit atau yang disebut dengan analisis 5C (Kasmir, 2012), yang terdiri atas: (a) character yaitu sifat/watak calon debitur benar-benar dapat dipercaya, (b) capacity (capability) yaitu kemampuan calon nasabah dalam membayar kredit dihubungkan dengan kemampuan mengelola bisnis dan mencari laba, (c) capital bertujuan untuk mengetahui sumbersumber pembiayaan yang dimiliki nasabah terhadap usaha yang akan dibiayai oleh bank, (d) collateral yaitu jaminan yang diberikan calon nasabah baik fisik maupun non fisik, jaminan sebaiknya melebihi jumlah kredit yang diberikan, (e) condition yaitu menilai kondisi ekonomi sekarang dan mendatang sesuai sektor masing masing.

Penilaian kredit dapat juga menggunakan metode analisis 7P, yaitu personality, party, purpose, prospect, payment, profitability, dan protection. (Kasmir, 2012). Personality untuk menilai nasabah dari segi kepribadian/tingkah laku sehari-hari, sikap, emosi, serta tindakan nasabah dalam menghadapi suatu masalah. Party yaitu mengklasifikasikan nasabah berdasarkan modal, loyalitas, dan karakternya. Purpose untuk mengetahui tujuan nasabah mengambil kredit (modal kerja atau investasi, konsumtif atau produktif, dan lain lain) dan jenis kredit yang diinginkan nasabah. Prospect untuk menilai usaha nasabah pada masa yang akan datang menguntungkan dan berkelanjutan atau tidak. Payment yaitu untuk mengetahui sumber dana yang dimiliki nasabah untuk mengembalikan kredit. Profitability untuk menganalisis kemampuan nasabah mencari laba. Protection bertujuan menjaga agar usaha atau jaminan mendapatkan perlindungan yang berbentuk jaminan barang, orang, dan asuransi.

Penilaian kredit menurut Hasibuan (2008) menggunakan metode analisis 3R, yaitu returns, repayments, dan risk bearing ability. Returns adalah penilaian terhadap hasil yang akan dicapai perusahaan calon debitur setelah memperoleh kredit. Apabila hasil diperoleh cukup untuk membayar pinjamannya sekaligus membantu mengembangkan usaha calon debitur. Repayment adalah menganalisis kemampuan, jadwal, dan jangka waktu pembayaran kredit oleh calon debitur. Risk bearing ability adalah memperhitungkan kemampuan perusahaan calon debitur dalam menghadapi resiko. Kemampuan perusahaan menghadapi resiko ditentukan oleh besarnya modal, struktur organisasi, jenis bidang usaha, dan manajemen perusahaan yang bersangkutan. Kredit akan diberikan apabila perusahaan memiliki risk bearing ability yang rendah.

Pemberian kredit sangat memperhitungkan prinsip collateral atau jaminan yang penting untuk menjaga keamanan kredit bank. Langkah 
pengamanan tersebut dilakukan untuk meniadakan atau memperkecil resiko. Oleh karena itu bank dilarang memberikan kredit tanpa jaminan sesuai dengan Pasal 2 ayat (1) Surat Keputusan Direksi Bank Indonesia Nomor 23/69/KEP/DIR tanggal 28 Februari 1991 tentang Jaminan Pemberian Kredit. Kredit yang diberikan oleh bank terdapat resiko sehingga dalam pelaksanaannya bank harus memperhatikan asas-asas perkreditan yang sehat dan baik.

Perkembangan teknologi mendorong usaha perbankan untuk meningkatkan layanannya dengan memberikan kemudahan kepada nasabah. Apalagi dengan semakin ketatnya persaingan antar bank dan juga perusahaan financial technology yang banyak bermunculan untuk menunjang kegiatan bisnis yang lebih efektif dan efisien. Keberadaan fintech diharapkan dapat mengembangkan Usaha Menengah Kecil dan Mikro, khususnya untuk pembiayaan serta pemasaran produknya (Rizal, Maulina, \& Kostini, 2018) Bank membuat suatu sistem kredit secara online yang dinilai akan lebih mempermudah segala kegiatan bisnis seseorang. Kredit yang dilakukan secara online dengan berbagai kemudahan rentan mengalami berbagai resiko, baik yang dialami oleh kreditur maupun debitur.

Sistem kredit online adalah salah satu produk yang terinspirasi oleh financial technology sebagai suatu bentuk kemudahan dalam memberikan kredit. Peraturan Otoritas Jasa Keuangan (OJK) Nomor 77/POJK.01/2016 tentang Layanan Pinjam-meminjam Berbasis Teknologi Informasi (disebut sebagai POJK 77/ POJK.01/2016) sebagai dasar hukum sistem pinjam-meminjam dengan sistem elektronik yang biasa disebut financial technology. Bank Indonesia juga mengeluarkan Peraturan Bank Indonesia Nomor 19/12/PBI/2017 tentang Penyelenggaraan Teknologi Finansial yang dijadikan sebagai dasar hukum bagi perbankan yang menyelenggarakan fasilitas kredit secara online. Keberadaan pinjaman online juga telah lebih terjaga keamanannya dengan adanya regulatory sandbox ruang uji terbatas untuk menguji penyelenggaraan teknologi finansial serta produk, layanan, teknologi dan model bisnisnya (Kholis, 2018). Berdasarkan latar belakang di atas, dalam tulisan ini akan membahas tentang keabsahan suatu perjanjian dalam kredit secara online dan pemberian jaminan pada kredit online sebagai perwujudan prinsip 5C dalam perbankan.

\section{METODE}

Kajian ini menggunakan metode yuridis normatif yaitu dengan mengumpulkan bahan hukum primer (Soekanto \& Mamudji, 2010). Pendekatan yang digunakan adalah pendekatan perundang-undangan (statute approach) dan pendekatan konseptual (conceptual approach). Pendekatan perundang-undangan dilakukan dengan menelaah undang-undang dan peraturan yang berada di bawahnya yang berkaitan dengan isu hukum kredit yang dilakukan secara online. Kajian dilakuan dengan mencari ratio legis dan dasar ontologis lahirnya undang-undang yang digunakan dalam pelaksanaan kredit online. Pendekatan konseptual dilakukan dengan mencari teori serta doktrin yang telah ada untuk dijadikan suatu acuan agar dapat memahami suatu pandangan-pandangan dan doktrin-doktrin dalam membangun suatu argumentasi hukum dalam memecahkan isu yang sedang dihadapi.

Sumber bahan hukum yang digunakan adalah sumber hukum primer dan sumber hukum sekunder yang berasal dari buku maupun karya ilmiah lainnya. Sumber hukum primer yang digunakan adalah Kitab Undang-Undang Hukum Perdata (Burgerlijk Wetboek), UndangUndang Perbankan, dan undang-undang yang berkaitan dengan jaminan. Analisis bahan hukum dilakukan dengan cara interpretasi terhadap undang-undang ataupun peraturan yang berlaku, baik yang sudah terlaksana dengan baik maupun yang belum terlaksana dengan baik.

\section{HASIL DAN PEMBAHASAN}

\section{Keabsahan Perjanjian dalam Sistem Kredit Online}

Istilah kontrak atau perjanjian seringkali dipahami secara rancu, kedua istilah tersebut sering dimaknai berbeda. Beberapa peraturan juga menggunakan kedua istilah tersebut seolah-olah berbeda sebagaimana istilah yang digunakan dalam aturan mengenai pertambangan. Terdapat dua istilah yang sangat popular dalam pertambangan yaitu kontrak karya dalam pengusahaan pertambangan mineral dan perjanjian karya dalam pengusahaan tambang batu bara. Kontrak karya atau kontrak digunakan untuk pertambangan mineral dan perjanjian karya 
atau perjanjian digunakan untuk pertambangan batu bara (Awaliyah, 2014).

Buku III BW yang berjudul PerikatanPerikatan yang Lahir dari Kontrak atau Perjanjian mengindikasikan bahwa kedua istilah tersebut dimaknai sama (Hernoko, 2008). Pengertian kontrak diatur dalam Pasal 1313 BW yang menyatakan bahwa suatu perjanjian adalah suatu perbuatan satu orang atau lebih yang mengikatkan dirinya terhadap satu orang atau lebih. Perjanjian atau kontrak merupakan salah satu dasar hukum yang menimbulkan perikatan. Definisi perikatan menurut doktrin para ahli adalah hubungan dalam bidang harta kekayaan antara dua orang atau lebih, dimana pihak yang satu (debitur) wajib melakukan suatu prestasi, sedangkan pihak yang lain (kreditur) berhak atas prestasi itu (Hernoko, 2014). Tidak semua perjanjian mengakibatkan perikatan. Perjanjian yang dapat mengakibatkan perikatan hanya perjanjian obligatoir, yaitu perjanjian yang menimbulkan kewajiban bagi para pihak yang terkait (Prawanirah, 2017).

Perjanjian adalah peristiwa dua orang yang saling berjanji untuk melaksanakan suatu perbuatan (Subekti, 1979). Hal tersebut menimbulkan hubungan hukum antara dua orang tersebut atau yang disebut dengan perikatan. Perjanjian tersebut menerbitkan suatu perikatan antara dua orang yang membuatnya. Bentuk perjanjian adalah rangkaian perkataan yang mengandung janji atau kesanggupan yang diucapkan atau ditulis. Dalam hubungan antar pihak terdapat beberapa bentuk pemenuhan hak atau kewajibannya. Masing-masing pihak memiliki hak dan kewajiban, sesuai dengan isi atau substansi perjanjian.

Kata perikatan mempunyai arti yang lebih luas daripada perjanjian. Karena perikatan tidak hanya mengandung pengertian hubungan hukum yang timbul dari perjanjian saja, tetapi juga perihal hubungan hukum yang sama sekali tidak bersumber pada suatu perjanjian, yaitu perihal perikatan yang timbul dari undangundang. Pasal 1313 BW mengatakan bahwa "Suatu perbuatan dengan mana satu orang atau lebih mengikatkan dirinya terhadap satu orang lain atau lebih". Dari ketentuan pasal tersebut maka persetujuan yang dimaksud adalah suatu persetujuan yang bersifat sepihak, yaitu persetujuan yang hanya menimbulkan kewajiban pada satu pihak saja (Hernoko, 2014). Perjanjian atau kontrak merupakan salah satu dasar hukum yang menimbulkan perikatan.

Sumber perikatan adalah perjanjian. Pada umumnya prinsip dalam hukum kontrak ada tiga (Dirjosisworo 2013), yaitu: (a) prinsip konsensual, perjanjian-perjanjian diadakan melalui konsensus atau kesepakatan para pihak, (b) prinsip pemenuhan kewajiban, para pihak harus memenuhi kewajiban masing-masing sebagaimana diatur dalam Pasal 1375 BW yang mengungkapkan bahwa perjanjian adalah undang-undang bagi masing-masing pihak, (c) prinsip kebebasan berkontrak, perjanjian dilaksanakan atas kebebasan para pihak untuk terikat atau tidak terikat dalam suatu perjanjian. Perjanjian adalah kesepakatan yang dilakukan oleh dua orang atau lebih yang memuat syarat sebagaimana diatur dalam Pasal 1320 BW. Syarat sahnya perjanjian ada empat, yaitu kesepakatan, kecakapan, suatu hal tertentu, dan suatu sebab yang halal. Kesepakatan yang mengikatkan dirinya, hal ini terdapat kesepakatan antara nasabah dan bank selaku pemilik fitur kredit online akan mengikat keduanya. Kecakapan membuat suatu perikatan, pihak bank kredit online harus memastikan bahwa nasabahnya adalah orang yang telah cakap dan dapat melakukan perbuatan hukum. Suatu hal tertentu, pemberian kredit secara online ini merupakan alasan yang digunakan untuk mendapatkan fasilitas kredit dengan cara yang mudah karena semua orang dapat mengakses permohonan kredit dengan cara yang mudah. Suatu sebab yang halal, itikad baik dalam melakukan suatu hubungan dalam perjanjian, fitur kredit online harus dapat memastikan bahwa nasabah yang ingin mengajukan permohonan kredit ini memiliki itikad baik dan dapat dipertanggungjawabkan.

Perikatan dalam perjanjian kredit adalah hubungan hukum antara dua orang atau dua pihak, pihak yang satu berhak menuntut suatu hal dari pihak yang lain, sedangkan pihak lain mempunyai kewajiban untuk memenuhi tuntutan. Pihak yang berhak menuntut sesuatu dinamakan kreditur atau yang berpiutang sedangkan pihak yang berewajiban memenuhi tuntutan itu dinamakan debitur atau yang berhutang. Bunga kredit harus mendasarkan pada standarisasi penetapan bunga dengan lembaga jasa keuangan lainnya (Putra \& Budiana, 2019).

Syarat sahnya perjanjian itu yang menjadi dasar bagi kreditur dan debitur untuk melakukan 
suatu prestasi yang harus disepakati keduanya. Dengan kemudahan kredit online ini sangat dimungkinkan adanya wanprestasi pada salah satu pihak, wanprestasi biasanya dilakukan oleh debitur sehingga sering kali muncul adanya kredit macet. Wanprestasi yang dilakukan seorang debitur dapat berupa: (a) tidak melakukan apa yang disanggupi akan dilakukannya, (b) melaksanakan apa yang dijanjikannya, tetapi tidak sebagaimana yang dijanjikan, (c) melakukan apa yang dijanjikannya tetapi terlambat, dan (d) melakukan sesuatu yang menurut perjanjian tidak boleh dilakukannya (Subekti, 2010).

Perjanjian kredit adalah perjanjian obligatoir maka secara otomatis kreditur akan mendapatkan jaminan umum dari debitur. Menurut ketentuan Pasal 1131 BW kreditur berkedudukan sebagai kreditur konkuren yang sejajar dengan kreditur konkuren lainnya (Usanti \& Bakarbessy, 2013). Persamaan kedudukan terhadap harta debitur tidak ada yang diutamakan dalam pelunasan, meskipun di antara mereka ada yang mempunyai tagihan yang lebih lama. Pembayaran yang didapatkan adalah berdasarkan perbandingan besaran tagihan yang dibagi secara proporsional sebagaimana ketentuan Pasal 1132 BW.

\section{Pemberian Jaminan pada Kredit Online Sebagai Perwujudan Prinsip 5C dalam Perbankan}

Kredit dilihat dari sudut bahasa berarti kepercayaan, bahwa apabila seseorang atau suatu badan usaha mendapatkan fasilitas kredit dari bank, maka orang atau badan usaha tersebut telah mendapat kepercayaan dari bank pemberi kredit. Kredit adalah pemberian prestasi berupa uang atau barang dengan balas prestasi atau kontra prestasi yang akan terjadi pada waktu mendatang. Kredit bersifat kooperatif antara pemberi kredit (kreditur) dan penerima kredit (debitur). Pemberi dan penerima kredit mendapat keuntungan dan saling menanggung resiko. Kredit dalam arti luas mendasarkan pada kepercayaan, resiko, dan pertukaran ekonomi pada masa mendatang (Simorangkir, 1988).

Kredit ditinjau dari segi ekonomi diartikan sebagai penyediaan uang dan tagihan. UndangUndang Perbankan menyatakan bahwa kredit didasarkan pada penyediaan uang atau tagihan yang dapat dipersamakan dengan hal tersebut yang didasarkan pada persetujuan atau kesepakatan dalam pinjam-meminjam untuk melunasi hutangnya setelah jangka waktu dengan jumlah bunga tertentu. Empat unsur dalam perjanjian kredit yaitu kepercayaan, waktu, resiko, dan prestasi (Simorangkir, 1988). Kepercayaan, pemberian kredit berdasarkan pada keyakinan bank bahwa kredit tersebut dapat dibayarkan oleh debiturnya sesuai dengan jangka waktu yang diperjanjikan. Waktu, berarti pemberian kredit oleh bank dengan pembayaran kembali oleh debitur dilakukan pada waktu yang berbeda, terdapat tenggang waktunya. Resiko, setiap pemberian kredit jenis apapun itu akan mengandung resiko yang terjadi dalam jangka waktu antara pemberian kredit dengan pembayaran kembali. Hal ini berarti semakin panjang jangka waktu kredit semakin besar resikonya. Prestasi, setiap kesepakatan yang terjadi antara bank dengan debitur mengenai suatu pemberian kredit, maka pada saat itu pula akan terjadi suatu prestasi dan kontra prestasi.

Perjanjian kredit merupakan perjanjian perorangan yang menimbulkan hak perorangan (persoonlijk recht), yaitu semua hak yang timbul karena adanya hubungan utang piutang yang bersifat sementara, pengaturannya dapat dilihat dalam Pasal 1315 BW jo Pasal 1340 BW. Hak perorangan memiliki lima ciri, yaitu: (a) hak relatif, hanya dapat ditegakkan pada pihak tertentu, (b) tidak ada asas droit de suite, dengan beralihnya hak milik maka hak perseorangan berhenti sejak dijualnya benda tersebut, (c) kedudukan pemegang hak perorangan sederajat, tidak ada yang didahulukan, (d) berkedudukan sebagai kreditur konkuren (Pasal 1132 BW), (e) gugatannya disebut penggugat perseorangan, orang hanya dapat mengajukan gugatan pada pihak lawannya (Usanti \& Bakarbessy, 2010).

Pemberian kredit terikat dengan prinsip collateral atau jaminan. Jaminan merupakan hal penting dalam menjaga keamanan kredit bank. Langkah pengamanan dilakukan karena pemberian kredit rentan menghadapi resiko (degree of risk) atau setidaknya memperkecil resiko. Oleh karena itu bank dilarang memberikan kredit tanpa jaminan sesuai dengan Pasal 2 ayat (1) Surat Keputusan Direksi Bank Indonesia Nomor 23/69/KEP/DIR tanggal 28 Februari 1991 tentang Jaminan Pemberian Kredit. Kredit yang diberikan oleh bank mengandung resiko, sehingga dalam pelaksanaannya bank harus memperhatikan asas-asas perkreditan yang sehat. 
Hal tersebut berbeda dengan Undang Undang Nomor 10 Tahun 1998 tentang Perbankan yang menyatakan bahwa jaminan tidak merupakan syarat mutlak. Ketentuan Pasal 8 Undang-Undang Perbankan memungkinkan diberikan kredit tanpa jaminan. Penjelasan Pasal 8 Undang Undang Perbankan menyatakan bahwa pemberian kredit hanya mendasarkan pada analisis mengenai kemampuan nasabah untuk mengembalikan pinjamannya. Jaminan sebagai tindakan preventif untuk menghindari atau menghilangkan resiko hampir dapat dikatakan tidak ada sehingga timbul peluang-peluang bagi debitur yang mempunyai itikad kurang baik untuk mengambil keuntungan dari celah tersebut.

Ketentuan Pasal 8 Undang-Undang Perbankan menyatakan bahwa jaminan bukan merupakan syarat mutlak dan hanya merupakan salah satu syarat yang harus dipenuhi, namun di dalam kenyataannya dalam pemberian kredit pihak bank selalu mensyaratkan adanya jaminan berupa harta milik debitur (Rahman, 2009). Jaminan adalah tanggungan yang diberikan oleh debitur dan/atau pihak ketiga kepada kreditur karena pihak kreditur mempunyai suatu kepentingan bahwa debitur harus memenuhi kewajiban dalam suatu perikatan. Jenis jaminan dalam hukum perdata dapat dibedakan menjadi dua, yakni jaminan kebendaan dan jaminan perorangan (Sofwan, 2003).

Pelaksanaan pinjam-meminjam uang atau kredit pada umumnya dipersyaratkan adanya perjanjian tambahan berupa perjanjian jaminan demi keamanan pemberian kredit. Jaminan hutang adalah pemberian keyakinan kepada pihak kreditur atas pembayaran hutang. Perjanjian jaminan bersifat assessoir, yaitu perjanjian yang mengikuti jaminan pokoknya berupa perjanjian utang piutang atau kredit. Jenis jaminan hutang dapat berupa jaminan kebendaan yang akan menimbulkan hak kebendaan atau jaminan perorangan, biasa disebut dengan borgtocht yang akan menimbulkan hak perorangan. Pada umunya kreditur memilih menggunakan jaminan kebendaan karena dengan memegang jaminan kebendaan maka kedudukan kreditur akan menjadi kreditur preferen dan hak kebendaan atas jaminan tersebut akan beralih kepada kreditur yang akan memberikan hak untuk mendapat pembayaran hutang terlebih dahulu atas eksekusi terhadap benda-benda jaminan.
Jaminan kebendaan adalah jaminan atas benda tertentu milik debitur atau milik pihak ketiga yang diperuntukan secara khusus bagi kepentingan kreditur tertentu pula. Jaminan kebendaan yang dibuat oleh para pihak adalah perjanjian kebendaan bukan perjanjian obligatoir (Usanti \& Bakarbessy, 2008). Jaminan kebendaan memiliki beberapa ciri khusus yang juga merupakan alasan para kreditur memilih menggunakan jaminan kebendaan daripada jaminan perorangan. Ciri ciri tersebut adalah bersifat absolut, prioritas, preferensi, dan droit de suite. Bersifat absolut maksudnya dapat ditegakkan kepada siapa saja, tidak hanya pada rekan sekontraknya saja. Berbeda dengan jaminan perorangan yang tidak bersifat absolut sehingga hanya bisa ditegakkan pada rekan sekontraknya saja. Memiliki asas prioritas yang berarti bahwa hak kebendaan yang lahir terlebih dahulu maka akan lebih didahulukan daripada hak yang lahir kemudian. Memiliki asas preferensi yaitu kreditur berhak untuk memperoleh pelunasan terlebih dahulu dibandingkan kreditur lainnya. Kreditur lainnya dalam hal ini adalah kreditur yang tidak memegang hak kebendaan atau kreditur konkuren. Bersifat Droit de Suite berarti bahwa hak kebendaan akan mengikuti dimana pun bendanya berada.

Ketentuan Pasal 8 Undang-Undang Perbankan dan penjelasannya memberikan arti yang lain terhadap kata agunan. Jaminan pemberian kredit diartikan sebagai keyakinan atas kemampuan dan kesanggupan debitur untuk melunasi hutangnya sesuai dengan yang diperjanjikan. Dengan kata lain bahwa Undang Undang Perbankan telah memberikan arti yuridis bagi jaminan pemberian kredit bukan sebagai agunan kredit, sedangkan agunan kredit hanya merupakan salah satu unsur dari jaminan pemberian kredit. Dalam praktik dan dalam tulisan-tulisan mengenai perbankan khususnya kredit perbankan, arti yuridis dari jaminan pemberian kredit sebagaimana yang diatur dalam Undang-Undang Perbankan tidak dipergunakan.

Pelaksanaan perjanjian kredit sebagai perjanjian pokok memerlukan perjanjian jaminan sebagai penerapan prinsip kehati-hatian bank sebagai pemberi pinjaman. Perjanjian jaminan bertujuan agar bank tidak dirugikan apabila debitur tidak dapat melunasi hutangnya. Jaminan yang digunakan untuk melengkapi perjanjian kredit tersebut adalah jaminan kebendaan. 
Penggunaan jaminan kebendaan digunakan kreditur sebagai pemegang jaminan dengan kedudukan yang diutamakan, didahulukan, dan dimudahkan untuk mengambil pelunasan dan memberikan suatu tekanan psikologis terhadap debitur untuk memenuhi kewajibannya dengan baik (Satrio, 2002).

Kredit online yang banyak dilakukan oleh perbankan yang menggunakan jasa financial technology ini harus didukung oleh sistem pengamanan yang tidak hanya mempermudah calon debitur untuk mengajukan kredit, tetapi juga harus memberikan jaminan tidak akan menimbulkan kerugian bagi. Bank Indonesia mengatur penyelenggaraan financial technology untuk mendorong inovasi di bidang keuangan dengan menerapkan prinsip perlindungan konsumen serta manajemen resiko dan kehatihatian untuk menjaga stabilitas sistem keuangan dan sistem pembayaran yang efisien, lancar, aman, dan andal. Hal tersebut telah dituangkan dalam tujuan financial technology yang telah diatur oleh Peraturan Bank Indonesia Nomor 19/12/PBI/2017.

Fitur online yang terdapat dalam aplikasi kredit online pada perbankan ini, harusnya memuat suatu kolom yang berisi jaminan yang diberikan oleh debitur kepada kreditur ini agar hak-hak kreditur tetap terjamin. Jaminan tentu merupakan salah satu ciri 5C yang mendukung kreditur untuk lebih berhati-hati dalam memberikan kredit kepada nasabah. Nilai jaminan tentu menyesuaikan dengan nilai hutang yang diajukan oleh nasabah. Tidak semua hutang harus diberikan suatu jaminan, tetapi semakin tinggi nilai hutang yang diajukan secara online, harus disertakan dengan jaminan sebagai salah satu wujud perlindungan bagi kreditur.

\section{SIMPULAN}

Perjanjian kredit online secara hukum sah akan tetapi belum memberikan kepastian hukum bagi para pihak yang tidak saling bertemu. Para pihak tidak dapat memastikan adanya itikad baik untuk melakukan perjanjian dan pihak bank tidak dapat memastikan calon debitur telah memenuhi prinsip-prinsip $5 \mathrm{C}$ untuk dapat melunasi kreditnya. Pemberian jaminan dalam pinjaman online menjadi salah satu unsur yang sangat penting untuk memberikan perlindungan bagi kreditur sebagai jaminan pelunasan hutangnya.

\section{DAFTAR RUJUKAN}

Awaliyah, S. (2014). Kontrak Karya Dan Perjanjian Karya Pengusahaan Pertambangan Batubara (KK / PKP2B). Jurnal Pendidikan Pancasila Dan Kewarganegaraan, 27(5), 111-121.

Dirjosisworo, S. (2013). Kontrak Bisnis (Menurut

Sistem Civil Law, Common Law, dan Praktek Dagang Internasional. Bandung: Mandar Maju.

Hartanto, A. (2015). Hukum Jaminan dan

Kepailitan. Surabaya: Laksbang Justitia,

Hasibuan, M.S.P. (2008). Manajemen Sumber

Daya Manusia. Jakarta: PT. Bumi Aksara.

Hernoko, A.Y. (2014). Hukum Perjanjian Asas

Proporsionalitas dalam Kontrak Komersial.

Jakarta: Kencana.

Imaniyati, N.S. (2010). Pengantar Hukum

Perbankan Indonesia. Bandung: Refika Aditama.

Kasmir. (2012). Bank dan Lembaga Keuangan Lainnya. Jakarta: Rajawali Pers.

Kholis, N. (2018). Perbankan dalam Era Baru Digital. Jurnal Economics, 12(1), 80-88. Panginan, E. K., \& Irwansyah. (2020). Fenomena Aplikasi dan Pinjaman Online Kredivo di Indonesia. Jurnal Komunikasi dan Kajian Media, 4(1). 12-26.

Prawanirah, U. (2017). Kewenangan Pemberi Fidusia Mengalihkan Kepemilikan Atas Objek Jaminan Fidusia Berupa Barang Dagangan Di Toko. Tesis. Surabaya: Fakultas Hukum Universitas Airlangga. Putra, K. S. W., \& Budiana, I. N. (2019). Perjanjian Kredit melalui Financial Technology dalam Lalu Lintas Hukum Bisnis. Jurnal Analisis Hukum, 2(1), 73-92.

Rahman, H. (2002). Aspek-Aspek Hukum Pemberian Kredit Perbankan di Indonesia. Bandung: Citra Aditya Bakti.Satrio, J. (2002). Hukum Jaminan, Hak Jaminan Kebendaan. Bandung: Citra Aditya Bakti. Rizal. M., Maulina E., dan Kostini, N. (2018). Fintech Salah Satu Pembiayaan bagi UMKM. Jurnal Pemikiran dan Penelitian Administrasi Bisnis dan Kewirausahaan, 3(2). 89-100.

Simorangkir, O.P. (2003). Seluk Beluk Bank Komersial. Jakarta: Aksara Persada Indonesia.

Soekanto, S \& Mamudji, S. (1985). Penelitian Hukum Normatif: Suatu Tinjauan Singkat. Jakarta: Rajawali. 
Sofwan, S.S.M. (2003). Hukum Jaminan di Indonesia. Yogyakarta: Liberty Offset.

Subekti. (1979). Hukum Perjanjian. Jakarta: Intermasa.

Supriyanto, E., \& Ismawati. N. (2019). Sistem Informasi Fintech Pinjaman Online Berbasis
Web. Jurnal Sistem Informasi, Teknologi Informasi dan Komputer, 9(2), 100-107. Usanti, T.P \& Bakarbessy, L. (2013). Buku Referensi Hukum Perbankan, Hukum Jaminan, Revka Petra Media. Surabaya: Revka Petra Media. 